\title{
Studies on amino acid metabolism in Lathyrus sativus Biosynthesis of homoserine and O-oxalylhomoserine
}

\section{J. PRZYBYLSKA}

Institute of Plant Genetics, Polish Academy of Sciences, Strzeszyńska 2/4, Poznań, Poland (Received: May 6, 1971.)

\section{Abstract}

Examination of free amino acid pool in Lathyrus sativus showed a rapid increase of homoserine and $\mathrm{O}$-oxalylhomoserine during germination. Isotopic experiments indicated that aspartic acid was an effective precursor of homoserine in Lathyrus sativus and suggested oxalic acid to be incorporated into O-oxalylhomoserine as an intact moiety. Similar trends of amino acid metabolism of Lathyrus sativus and of Pisum sativum have been discussed.

\section{INTRODUCTION}

Homoserine was shown to be a prominent free amino acid in vegetative organs, flowers, young pods (pericarps) and young seeds of numerous Lathyrus species (Przybylska 1963, 1964; Przybylska, Rymowicz 1965). Moreover, in young pods and young seeds of several Lathyrus species there were found large amounts of O-oxalylhomoserine (Przybylska, Pawełkiewicz 1965; Przybylska, Rymowicz 1965). High concentrations of both homoserine and O-oxalylhomoserine in metabolically active organs suggest these compounds to play a certain role in nitrogen metabolism.

Detailed analyses of O-oxalylhomoserine-containing ethanolic extracts of Lathyrus sativus indicated presence of a ninhydrin-negative derivative of homoserine, probably $\mathrm{N}$-oxalylhomoserine, concentration of the derivative being at least ten times lower than that of O-oxalylhomoserine (Przybylska, unpublished results). The presence of small amounts of the ninhydrin-negative derivative of homoserine in extracts containing O-oxalylhomoserine may be attributable to spontaneous rearrangement of the latter compound; several different O-acyl amino acids - including O-succinylhomoserine - were reported to undergo, at a slow rate, oxygen 
to nitrogen acyl transfer at physiological $\mathrm{pH}$ (F lavin, Sla u g h ter 1965). However, taking into regard the results of $\mathrm{Malathi}$ and coworkes (1970) who reported oxalylation of both $\alpha-\mathrm{NH}_{2}$ and $\gamma-\mathrm{OH}$ groups of homoserine by purified enzymes from Lathyrus sativus, the occurrence of $\mathrm{N}$-oxalylhomoserine as a natural compound cannot be excluded.

The main purpose of this study was to obtain information on biosynthesis of homoserine and its oxalyl derivative in Lathyrus sativus. It was, moreover, intended to get some knowledge about changes in the free amino acid pool at early stages of germination and about free amino acid composition in several kinds of organs of plants at an advanced phase of development.

There were followed changes in the free amino acid pool in Lathyrus sativus during 5 days of germination in dark. Quantitative determinations covered homoserine, O-oxalylhomoserine and two other compounds characteristic of Lathyrus sativus, namely homoarginine and $\beta-\mathrm{N}$-oxalyl- $\alpha$, $\beta$-diaminopropionic acid (ODAP). There was also examined free amino acid composition in shoot apices and leaves at time of bloom and in young pods. Taking into regard significant variations in free amino acid levels depending on environmental conditions, contents of homoserine, O-oxalylhomoserine, homoarginine and ODAP in the above mentioned organs were only approximately estimated with help of a semiquantitative method.

Isotopic experiments covered application of 14-C aspartic acid and 14-C glutamic acid to etiolated seedlings and administration of 14-C aspartic acid and 14-C oxalic acid to detached parts of green plants. While examining the plant material supplied with radioactive compounds special attention was given to conversion of the introduced amino acids to homoserine and incorporation of oxalic acid into O-oxalylhomoserine.

As O-oxalylhomoserine is a highly labile compound, all the analyses were performed with ammonia-treated extracts in which O-oxalylhomoserine is rapidly and irreversibly transformed into more stable $\mathrm{N}$-oxalylhomoserine. In view of the above mentioned relatively small proportion of the ninhydrin-negative derivative of homoserine in O-oxalylhomoserine-containing ethanolic extracts of Lathyrus sativus, and assuming that only O-oxalylhomoserine is metabolically active compound, all the data obtained for $\mathrm{N}$-oxąlylhomoserine in ammonia-treated extracts are referred to O-oxalylhomoserine. 


\section{MATERIALS AND METHODS}

Plant material

Seeds of Lathyrus sativus were obtained from the Experimental Station of the Institute of Soil Science and Cultivation of Plants, Przebędowo near Poznań.

Seedlings. Seeds were surface sterilized by immersion for 20 minutes in $0.2 \% \mathrm{HgCl}_{2}$, thoroughly washed with water, soaked for 10 hours in distilled water, and then germinated in the dark, on distilled water, at $22-24^{\circ} \mathrm{C}$. The analyses covered dry ungerminated seeds, and cotyledons and roots and shoots of two and five-day-old seedlings. Cotyledons and root-shoot axes of the seedlings were analysed separately. Five-day-old seedlings were used for isotopic experiments.

Green plants. Soaked seeds were planted into pots in a greenhouse (March). The plants were grown under standard conditions. The analyses and isotopic experiments covered shoot apices and leaves at time of bloom, and young pods. Shoot apices were cut off above the first leaf developed. Leaves, the first developed, from the top downwards, were cut off together with $2-3 \mathrm{~cm}$ segment of petiole. Young pods were cut off together with $0.5 \mathrm{~cm}$ portion of peduncle, approx. two weeks after perianth shedding.

\section{Isotopic experiments}

$\mathrm{R}$ a dio a ctive $\mathrm{m}$ at e rials. The following radioactive materials were obtained from commercial sources: L-aspartic acid-U-C ${ }^{14}$ (specific activity $91.8 \mathrm{mc} / \mathrm{mmole})$, L-glutamic acid-U-C ${ }^{14}$ (38.7 mc/mmole), oxalic acid-1, 2, C $\mathrm{C}^{14}(0.76 \mathrm{mc} / \mathrm{mmole})$.

Five-day-old etiolated seedlings were supplied with 14-C aspartic acid and 14-C glutamic acid. Radioactive substrates were injected directly into the cotyledons of intact seedlings with a Hamilton microliter syringe. One seedling received $10 \mu \mathrm{l}$ of a radioactive solution, half of the amount being introduced to each cotyledon. While feeding seedlings with radioactive aspartic acid each seedling received $0.011 \mu$ mole $(1 \mu \mathrm{c})$ of L-aspartic acid-U-C ${ }^{14}$. In experiments with radioactive glutamic acid each seedling obtained $0.026 \mu$ mole $(1 \mu c)$ of L-glutamic acid-U-C ${ }^{14}$. Duration of the experiments was 6 and 24 hours. In each experiment 5 seedlings were used.

Shoot apices, leaves and young pods were supplied with 14-C aspartic acid and 14-C oxalic acid. Solution of a radioactive compound was introduced by means of a Hamilton micropipette, through the cutting area of stem, petiole, or peduncle. Single organ received $10 \mu \mathrm{l}$ of a radioactive solution. In experiments with radioactive aspartic acid each organ received 0.011 umole $(1 \mu \mathrm{c})$ of L-aspartic acid-U-C ${ }^{14}$. In experiments with 
radioactive oxalic acid each organ received $1.14 \mu$ mole $(0.87 \mu \mathrm{c})$ of oxalic acid-1, 2, C ${ }^{14}$. Duration of the experiments was 6 hours. In each experiment at least two organs were supplied with a radioactive compound.

\section{Analytical procedures}

$\mathrm{R}$ e a g e $\mathrm{n} \mathrm{t} \mathrm{s}$. Common amino acids, homoserine and $\alpha, \beta$-diaminopropionic acid were obtained from commercial sources. O-oxalylhomoserine, $\beta$-N-oxalyl- $\alpha, \beta$-diaminopropionic acid (ODAP) and homoarginine were isolated, in crystalline form, in this laboratory from Lathyrus sativus. O-oxalylhomoserine was isolated from young pods as described by Przybylska and Pawełkiewicz (1965). ODAP and homoarginine were isolated from seeds by the methods described by $\mathrm{Murti}$ and coworkers (1964) and by Chwałek and Przybylska (1970), respectively. $\mathrm{N}$-oxalylhomoserine was obtained by treating O-oxalylhomoserine with ammonia.

Extraction. Samples of fresh plant material were extracted with four portions of $75^{\circ} \%$ ethanol, each time $5 \mathrm{ml}$ of the extractant being used for $1 \mathrm{~g}$ of fresh plant material, and $10 \mathrm{ml}$ - for $1 \mathrm{~g}$ of seed meal. Samples in which the content of homoarginine was determined were additionally extracted with ethanol $-1 \mathrm{~N}$ hydrochloric acid $(2: 1, \mathrm{v} / \mathrm{v})$ according to B ell (1962b). The combined extracts were evaporated under reduced pressure at $35^{\circ} \mathrm{C}$, and chlorophyll and lipids were subsequently removed by means of chloroform extraction. While extracting small samples of plant material supplied with radioactive compounds the combined extracts were evaporated to dryness and the dry residues were then extracted with two portions of water.

In case of analysing plant material unsupplied with radioactive zompounds, the amounts of fresh material used for extraction were as follows: ungerminated seeds (air dry) - $20 \mathrm{~g}$; two-day-old seedlings (80 seedlings): cotyledons $-27 \mathrm{~g}$, roots and shoots $-5 \mathrm{~g}$; five-day-old seedlings (60 seedlings): cotyledons $-11 \mathrm{~g}$, roots and shoots $-19 \mathrm{~g}$; different parts of green plants - $10 \mathrm{~g}$ samples.

The obtained extracts were alkalized with conc. ammonia and evaporated to dryness under reduced pressure, at $35^{\circ} \mathrm{C}$. The dry residues were resolved in conc. ammonia and left overnight. Ammonia was subsequently removed by repeated evaporation with water in the above conditions. The resulting residues were finally resolved in known amounts of water.

Fractionation of extracts on ion-exchange col u mns. The ammonia-treated extracts were passed through Dowex $50-\mathrm{X} 8$ columns (200-400 mesh) in $\mathrm{H}^{+}$form. The effluent and washings were collected into small fractions which were tested for $\mathrm{pH}$ value and ninhydrin reaction. Early acidic fractions which did not react with ninhydrin were combined into Fraction I. Later ninhydrin-positive, neutral- 
-to-lithmus fractions were combined into Fraction II. Amino acids displaced from the resin with $0.1 \mathrm{M}$ piperidine solution, or $1 \mathrm{M}$ ammonia (in case of quantitative determination of homoarginine), constituted Fraction III.

Aliquots of Fractions I-III were hydrolysed with $1 \mathrm{~N} \mathrm{HCl}$, for 3.5 hours, at $100^{\circ} \mathrm{C}$. The hydrolysis products of Fractions I and II were separated into ninhydrin-negative acidic compounds and amino acids by chromatography on Dowex 50-X8, in $\mathrm{H}^{+}$form.

Fractions I-III and products of their hydrolysis were analysed by means of paper chromatography and paper electrophoresis.

Chromatographic and electrophoretic techniques. Two-dimensional paper chromatography - used as a routine method for separation of amino acids - was performed after Wolfe (1957) as modified by $\mathrm{Przy}$ by ls ka (1960). In some cases chromatograms were run for a prolonged time (first direction -72 hours, second -24 hours) which resulted in a better resolution of the slowly moving amino acids but led to the loss of those of the highest $R_{f}$ values, e.g. isoleucine, leucine and phenylalanine.

One-dimensional paper chromatography - used for purification of $\mathrm{N}$-oxalylhomoserine - was performed by ascending technique, on Whatman No 3 paper, in ethanol-water-ammonia (sp. gr. 0.88$)(35: 13: 2$, by vol.) (H a rtley, Law s on 1960).

Paper electrophoresis was carried out in pyridinium acetate buffer, pH 4.5 (acetic acid-pyridine-water, 25:15:960, by vol.) (W a g n e r 1958) on sheets of Whatman No 3 paper, for 6 hours at $10 \mathrm{~V} / \mathrm{cm}$.

Chromatograms and electropherograms were developed with $0.4 \%$ solution of ninhydrin in acetone, with an addition of $0.2 \%$ of cobalt chloride. Ninhydrin-negative acidic compounds were located by spraying paper with bromocresol green indicator prepared as follows: sodium hydroxide solution (approx. $5 \%$ ) was added to $0.1 \%$ ethanol solution of bromocresol green until blue colour appeared; one volume of the above was mixed with four volumes of acetone, before use. Sugars were detected with silver nitrate reagent ( $\mathrm{S} \mathrm{mith} \mathrm{1960).}$

Quantitative determinations covered homoarginine and ODAP in ungerminated seeds, and homoarginine, ODAP, homoserine and $\mathrm{O}$-oxalylhomoserine in etiolated seedlings. The results were reproducible to within $\pm 5 \%$.

Homoarginine - Fraction III was applied to the column of Dowex $50-\mathrm{X} 8$ (200-400 mesh) in the ammonium form. Acidic and neutral amino acids were recovered in the effluent and washings. Basic amino acids were displaced with increasing concentrations of ammonia as reported previously (Chwa łek, Przybylska 1970). Homoarginine, uncontaminated with other amino acids, was eluted with $0.4 \mathrm{M}$ ammonia. 
Quantitative determination of homoarginine was performed by the method of Moore and Stein (1954).

Homoserine - Fractions containing acidic and neutral amino acids, separated from basic ones on Dowex 50-X8 in the ammonium form, were used for homoserine determinations. Homoserine was determined indirectly, in the form of corresponding lactone, as described by $\mathrm{V}$ o e l ke r t and G r a n t (1970). The lactone was separated from other amino acids on a short ion-exchange column and determined quantitatively by the modified method of Rosen (Rosen 1957; Grant 1963).

O-oxalylhomoserine - Determinations covered homoserine liberated on hydrolysis of Fractions I and were performed as described above.

ODAP - Determinations covered DAP liberated on hydrolysis of Fractions II. The procedure included separation of DAP from non-amino acid components of the hydrolysates by chromatography on Dowex 50$-\mathrm{X} 8$ in $\mathrm{H}^{+}$form and from trace amounts of dicarboxylic amino acids by chromatography on Dowex 1-X8 in the acetate form. DAP, recovered in the effluent from the Dowex 1 column, was subsequently determined by the method of Moore and $\mathrm{S}$ tein (1954).

Semiquantitative estimations covered homoserine, O-oxalylhomoserine and ODAP in shoot apices, leaves and young pods. Contents of O-oxalylhomoserine and ODAP were estimated on the basis of the amounts of the respective amino acids liberated on hydrolysis of the corresponding fractions.

Known amounts of the examined solutions were subjected to two-dimensional paper chromatography (estimation of homoserine) or paper electrophoresis (estimation of DAP). Standard amino acids (three levels) were subjected to similar procedures. Estimations based on visual comparison of colour intensity of the corresponding spots. The semiquantitative technique usually gives an accuracy of within about $30 \%$.

Radioactivity measurements. In case of liquid samples, $0.5-1.0 \mathrm{ml}$ volumes were placed in measuring vessels and poured over with $3 \mathrm{ml}$ of liquid scintillator after B a y (1960). The $14-\mathrm{C}$ activity was determined with the aid of scintillating counter SE 2 BJT, Warsaw, Poland. While the radioactivity measurements were carried out on paper, specific areas of paper were cut out, placed in the measuring vessels and poured over with the liquid scintillator.

R a dio a u tography. Radioautograms were prepared by exposing Foton-X-ray films ,Super R” to chromatograms for 50 days.

\section{RESULTS AND DISCUSSION}

As described in "Materials and methods", ammonia-treated ethanolic extracts of the analysed plant materials were fractionated by means of ion-exchange chromatography. The components of each extract were 
separated into three fractions: Fraction I, Fraction II and Fraction III. Fractions I and II comprised compounds unbound to strongly acidic ion-exchange resin, Fraction III contained free amino acids.

In Fractions I there were present N-oxalylhomoserine, other ninhydrin-negative acidic compounds and sugars. Fractions II contained ODAP and small amounts - in comparison with Fractions I - of ninhydrin-negative acidic compounds and of sugars.

On hydrolysis of Fractions I and II there were liberated - besides homoserine and DAP, respectively - several amino acids.

While discussing free amino acid composition, oxalylhomoserine, ODAP and other acidic compounds present in Fractions I and II and yielding amino acids on hydrolysis are taken into account. It is supposed that all the amino acids found in hydrolysates of Fractions I and II derive from corresponding acyl amino acids, presumably oxalyl amino acids. Such a suggestion bases on similar chromatographic behaviour of acidic compounds yielding amino acids on hydrolysis and on the relatively low specificity of oxalyl-transfer reactions (M a lathi, Padm a n a b a n, S a rma 1968, 1970).

Hereafter the terms Fraction I and Fraction II are used without any characterization of the fractions.

The results obtained are presented and discussed below under four headings which are followed by a general discussion.

I. CHANGES IN FREE AMINO ACID COMPOSITION IN LATHYRUS SATIVUS DURING GERMINATION IN THE DARK. COMPOSITION OF FREE AMINO ACIDS IN SHOOT APICES AND LEAVES AT TIME OF BLOOM AND IN YOUNG PODS OF LATHYRUS SATIVUS

Free amino acid composition of dry ungerminated seeds of Lathyrus sativus is distinguished by a particularly high level of homoarginine. Protein amino acids and ODAP occur in much lower concentration (Fig. 1, Tab. 1).

Quantitative and qualitative composition of free amino acids changes remarkably during germination in dark (Fig. 1, Tab. 1). Concentration of protein amino acids increases which reflects a progressive proteolysis. In general no marked differences in relative concentration of these compounds are observed between cotyledons and roots and shoots. However, roots and shoots of five-day-old etiolated seedlings show, in comparison with cotyledons, much higher relative level of asparagine. This indicates a rapid translocation of this amide to the growing parts.

The content of homoarginine does not decrease during five-day-period of germination. There may be only observed a slight translocation of this amino acid from cotyledons to roots and shoots (Fig. 1, Tab. 1). The results indicate that homoarginine, considered to constitute a highly concentrated form of nitrogen storage in seeds of different Lathyrus species 
Table 1

Changes in the content of homoserine, O-oxalylhomoserine, ODAP and homoarginine in Lathyrus sativus seedlings during 5 days of germination in the dark

Data in $\mu$ moles per seedling

\begin{tabular}{|c|c|c|c|c|c|c|c|c|c|c|c|c|}
\hline \multirow[b]{2}{*}{$\begin{array}{c}\text { Age } \\
\text { (days) }\end{array}$} & \multicolumn{3}{|c|}{ Homoserine } & \multicolumn{3}{|c|}{ O-oxalyihomoserine } & \multicolumn{3}{|c|}{ ODAP } & \multicolumn{3}{|c|}{ Homoarginine } \\
\hline & $\begin{array}{l}0 \\
\frac{0}{0} \\
\frac{0}{3} \\
\frac{3}{0} \\
0\end{array}$ & $\begin{array}{l}\overrightarrow{0} \\
\frac{0}{\omega} \\
+ \\
+ \\
\stackrel{0}{0} \\
\approx\end{array}$ & $\begin{array}{l}\vec{E} \\
\frac{\vec{E}}{2} \\
\frac{0}{0} \\
\frac{0}{b} \\
\sum\end{array}$ & $\frac{n}{\frac{n}{0}}$ & $\begin{array}{l}\text { o. } \\
\frac{0}{n} \\
+ \\
+ \\
\overrightarrow{0} \\
\approx\end{array}$ & 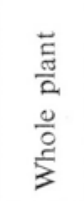 & $\frac{0}{0}$ & 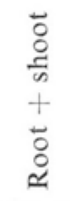 & 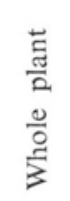 & $\begin{array}{l}\frac{n}{0} \\
\frac{0}{0} \\
\frac{0}{2} \\
0\end{array}$ & 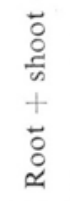 & $\begin{array}{l}\vec{E} \\
\frac{\tilde{J}}{2} \\
\frac{0}{0} \\
\bar{z}\end{array}$ \\
\hline $0^{*}$ & & & U & & & U & & & 1.06 & & & 7.20 \\
\hline 2 & 2.12 & 1.84 & 3.96 & 0.39 & 0.44 & 0.83 & 1.34 & 1.49 & 2.83 & 7.76 & 0.30 & 8.06 \\
\hline 5 & 2.04 & 2.56 & 4.60 & 3.65 & 8.24 & 11.89 & 0.83 & 2.56 & 3.39 & 7.31 & 0.61 & 7.92 \\
\hline
\end{tabular}

* dry ungerminated seeds

$\mathrm{U}$ - undetected

(B e 11 1962a, 1962b), is being utilized for metabolic processes at later phases of plant development.

In extracts of five-day-old etiolated seedlings the quantity of homoarginine was found to be slightly higher than in corresponding amounts of extracts of ungerminated seeds (Tab. 1). As it seems hardly likely in view of the presumable physiological role of homoarginine - that this amino acid is synthesized in germinating seeds, it may be suggested that seed meal represents less easily extractable material than five-day-old seedlings. However, biosynthesis of homoarginine in etiolated seedlings of Lathyrus sativus cannot be excluded before experiments with labelled precursors of this amino acid are carried out.

An increase in the content of ODAP on germination in dark (Tab. 1) may be attributed - in light of the results reported by $\mathrm{M} \mathrm{al}$ a th $\mathrm{i}$ and coworkers (1967) - to biosynthesis of this compound. Evidence provided by the above investigators on the biosynthesis of ODAP in germinating seeds of Lathyrus sativus clearly shows that non-protein amino acids, or their derivatives, present in mature seeds do not always serve as a source of nitrogen at germination.

While characterizing free amino acid pool in germinating seeds of Lathyrus sativus, it should be mentioned that $\gamma$-aminobutyric acid and $\alpha$-aminoadipic acid - unobserved, under analytical conditions, in ungerminated seeds - appeared as distinct spots on chromatograms of cotyledons of etiolated seedlings (Fig. 1). Both compounds belong to the non-protein amino acids commonly occurring in the plant kingdom.

Increasing levels of homoserine and O-oxalylhomoserine represent the most prominent feature of the changes in free amino acid composition 

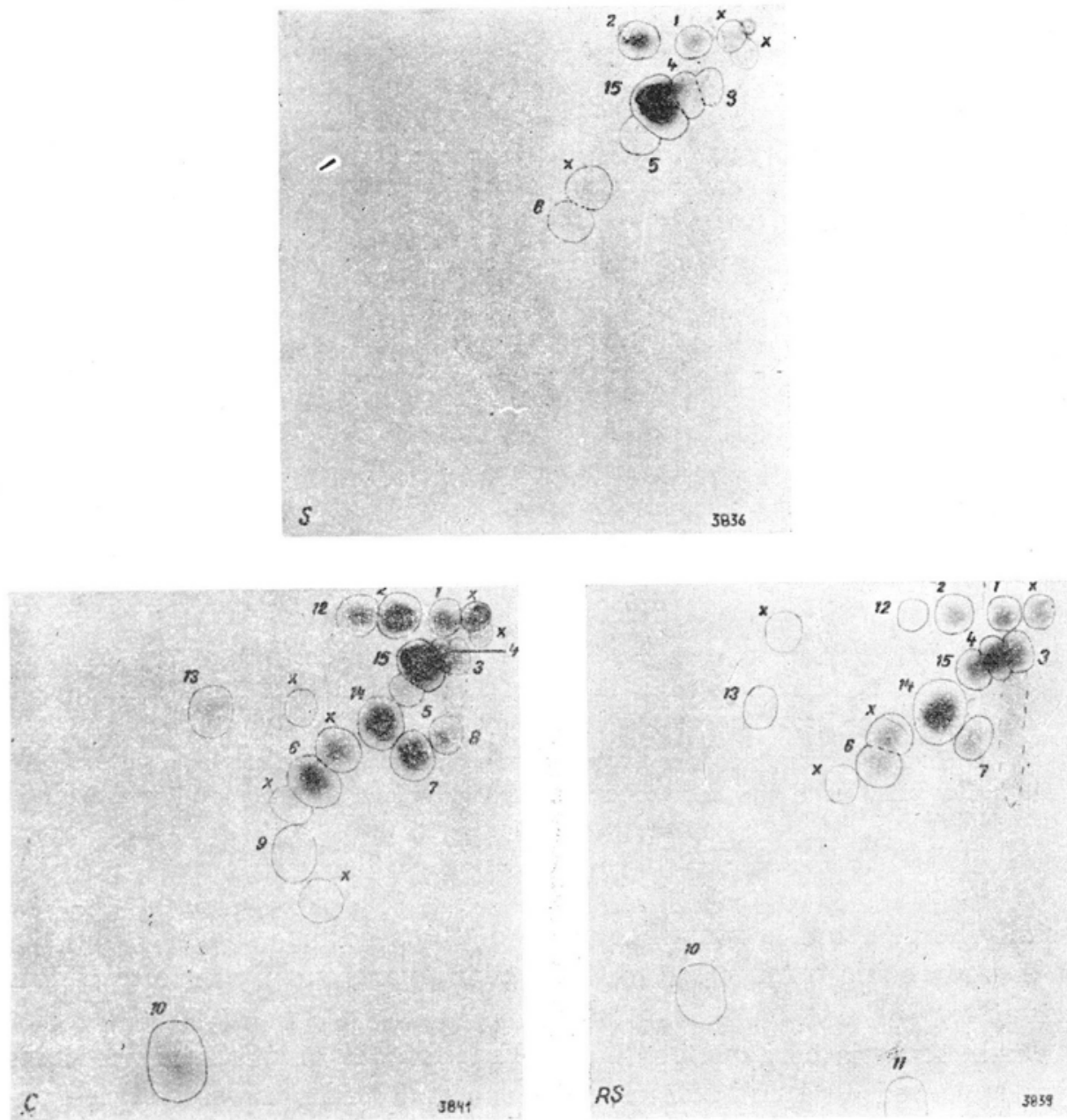

Fig. 1. Chromatograms of free amino acids of ungerminated seeds (S) and of cotyledons (C) and roots and shoots (RS) of 5-day-old etiolated seedlings of Lathyrus sativus. Aliquots applied onto the chromatograms are equivalent to $1 / 10$ of the analysed organs

Key to the spots: 1 - aspartic acid; 2 - glutamic acid; 3 - asparagine and lysine; 4 glutamine and arginine; 5 - glycine; 6 - alanine; 7 - serine; 8 - histidine; 9 - proline; 10 - methionine and/or valine; 11 - threonine; $12-\alpha$-aminoadipic acid; $13-\gamma$-aminobutyric acid; 14 - homoserine; 15 - homoarginine; $x$-unidentified compound.

Remark of Figures 1 and 3: Another series of chromatograms, run for a shorter time (see: Materials and methods), revealed in all the examined extracts small or trace amounts of the following amino acids of high $R_{f}$ values: isoleucine, leucine and phenylalanine.

at germination (Fig. 1, Tab. 1). The compounds were not observed in dry ungerminated seeds. Consequently, the appearance of relatively large amounts of homoserine and O-oxalylhomoserine in five-day-old seedlings indicates that synthesis of these compounds belongs to the principal metabolic processes taking place on germination. Particularly high level of 


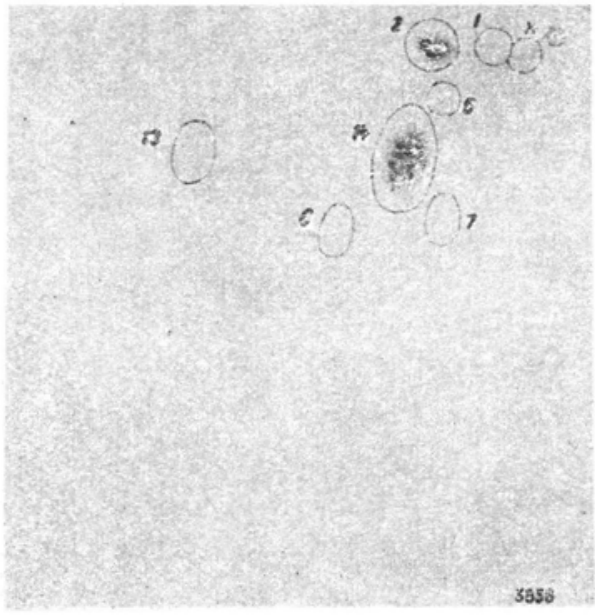

Fig. 2

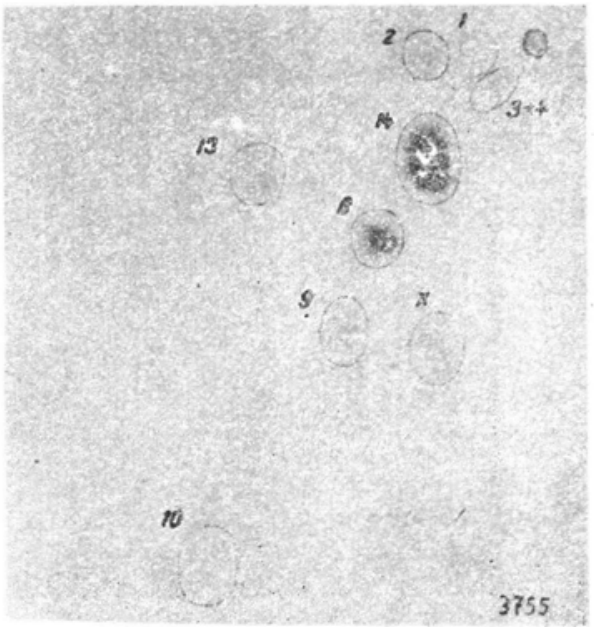

Fig. 3

Fig. 2. A chromatogram of amino acids liberated on hydrolysis of Fraction I of cotyledons of 5-day-old etiolated seedlings of Lathyrus sativus. An aliquot applied onto the chromatograms is equivalent to $1 / 10$ of a cotyledon pair

Fig. 3. A chromatogram of free amino acids of leaves of Lathyrus sativus. An aliquot applied onto the chromatogram is equivalent to $3 \mathrm{mg}$ of dry matter For key to the spots see fig. 1.

O-oxalylhomoserine in root-shoot axes of the seedlings suggests that homoserine is being transported to the growing parts mostly in form of this derivative.

On hydrolysis of Fractions I and Fractions II of etiolated seedlings there appeared - apart from homoserine and DAP, respectively - as-

Table 2

Semiquantitative estimation of homoserine, O-oxalylhomoserine and ODAP in shoot apices, leaves and young pods of Lathyrus sativus Data in $\mu$ moles per $10 \mathrm{mg}$ of dry matter

\begin{tabular}{l|c|c|c}
\multicolumn{1}{c|}{ Plant organs } & Homoserine & $\begin{array}{c}\text { O-oxalyl- } \\
\text { homoserine }\end{array}$ & ODAP \\
\hline Shoot apices & 1.7 & 3.4 & $<0.1$ \\
Leaves & 1.7 & 1.1 & $<0.1$ \\
Young pods & 1.9 & 3.0 & $<0.1$ \\
\hline
\end{tabular}

partic acid, glutamic acid, glycine, alanine, serine and $\gamma$-aminobutyric acid. The amino acids formed minor constituents only except for glutamic acid which liberated in fairly large amounts on hydrolysis of Fraction I of cotyledons of five-day-old etiolated seedlings (Fig. 2). 
As concerns the examined parts of green plants, high concentration of both homoserine and O-oxalylhomoserine was found in shoot apices and in young pods; in leaves homoserine likewise represented the predominant free amino acid (Fig. 3) while the relative level of O-oxalylhomoserine was somewhat lower (Tab. 2). Protein amino acids were present in relatively small amounts, and no remarkable differences in their relative levels were noted between the examined organs. Also $\gamma$-aminobutyric acid and ODAP formed minor constituents only.

Fractions I and Fractions II of the examined parts of green plants yielded on hydrolysis — besides of homoserine and DAP, respectively trace amounts of aspartic acid, glutamic acid and glycine.

II. RADIOACTIVITY DISTRIBUTION IN AMMONIA-TREATED ETHANOLIC EXTRACTS OF COTYLEDONS AND OF ROOTS AND SHOOTS OF FIVE-DAY-OLD ETIOLATED SEEDLINGS OF LATHYRUS SATIVUS SUPPLIED WITH 14-C ASPARTIC ACID AND 14-C GLUTAMIC ACID

Data presented in table 3 indicate that, under conditions of the experiment, amino acids supplied to the seedlings and the products of their metabolism were translocated from cotyledons to the growing parts in small extent only. Every fraction obtained from cotyledons, both 6 and 24 hours after supplying the labelled compound, exhibited significantly higher level of radioactivity when compared with corresponding fraction from roots and shoots.

Table 3

Radioactivity distribution in ammonia-treated ethanolic extracts of cotyledons and of roots and shoots of 5-day-old etiolated seedlings of Lathyrus sativus supplied with 14-C aspartic acid and 14-C glutamic acid. Expressed in $\mathrm{cpm} / 1$ organ $\times 10^{-2}$

\begin{tabular}{|c|c|c|c|c|c|}
\hline \multirow{2}{*}{$\begin{array}{l}\text { 14-C amino acid } \\
\text { administered }\end{array}$} & \multirow{2}{*}{$\begin{array}{c}\text { Time after } \\
\text { administra- } \\
\text { tion } \\
\text { (hours) }\end{array}$} & \multirow{2}{*}{$\begin{array}{l}\text { Plant organs } \\
\text { analysed }\end{array}$} & \multicolumn{3}{|c|}{ Fractions* } \\
\hline & & & I & II & III \\
\hline \multirow{4}{*}{ Aspartic acid } & \multirow[t]{2}{*}{6} & Cotyledons & $1987(212)^{* *}$ & 155 & 1856 \\
\hline & & Roots + shoots & $133 \quad(87)$ & 10 & 133 \\
\hline & \multirow{2}{*}{24} & Cotyledons & $1197(515)$ & 127 & 1155 \\
\hline & & Roots + shoots & $156(136)$ & 11 & 169 \\
\hline \multirow{4}{*}{ Glutamic acid } & \multirow{2}{*}{6} & Cotyledons & $1583(384)$ & 77 & 2374 \\
\hline & & Roots + shoots & $83 \quad(51)$ & 9 & 90 \\
\hline & \multirow{2}{*}{24} & Cotyledons & $1511(618)$ & 52 & 1471 \\
\hline & & Roots + shoots & $113 \quad(94)$ & 10 & 124 \\
\hline
\end{tabular}

* Fraction III contains free amino acids. Composition of the remaining fractions is given in the text.

** Values in parantheses refer to amino acids liberated on hydrolysis. 
Fractions afforded by cotyledons show, in general, lower radioactivity when duration of the experiment is prolonged to 24 hours. This decline must be largely attributed to a loss of a part of $14-\mathrm{C}$ in form of 14-C carbon dioxide. At the same time, in corresponding fractions from roots and shoots there may be observed a slight increase in radioactivity level which reflects dislocation of labelled compounds from cotyledons to the growing parts.

Concerning radioactivity level of individual fractions, relatively high radioactivity of Fractions I is to be pointed out. Radioactivity of Fractions III, containing free amino acids, shows similar level. Fractions II exhibited only a slight radioactivity.

Radioactivity distribution within particular fractions is presented below.

Radioactivity distribution among free amino acids (Fraction III)

Figure 4 shows radioautograms of free amino acids of cotyledons of etiolated seedlings of Lathyrus sativus supplied with 14-C labelled aspartic and glutamic acids. It is evident that after 6 hours from administration of 14-C aspartic acid to the seedlings, strong radioactivity was revealed in the supplied substrate, less radioactivity was found in homoserine while asparagine, glutamic acid, glutamine and alanine were only weakly labelled compounds. Six hours after supplying 14-C glutamic acid, $\gamma$-aminobutyric acid proved to be the predominant labelled compound, less radioactivity was found in glutamic acid and very weak radioactivity was revealed in homoserine, glutamine, aspartic acid and asparagine. Twenty four hours after supplying a labelled compound, either aspartic or glutamic acid, homoserine largely contributed to the total radioactivity of free amino acid pool of cotyledons. The results indicate that aspartic acid is more rapidly converted to homoserine than glutamic acid which undergoes a very rapid decarboxylation to $\gamma$-aminobutyric acid.

Radioactivity distribution among free amino acids in roots and shoots was similar to that in cotyledons. It should be mentioned, however, that 24 hours after supplying 14-C aspartic acid to the seedlings, the relative radioactivity of homoserine and asparagine was higher in roots and shoots than in cotyledons which indicates a rapid transport of these amino acids to the growing parts. To the contrary, $\gamma$-aminobutyric acid exhibited lower relative radioactivity in roots and shoots than in cotyledons of seedlings supplied with 14-C glutamic acid.

\section{Radioactivity distribution in Fractions I}

As shown in table 3, radioactivity of Fractions I is partly attributable to amino acids liberated on hydrolysis of these fractions. In cotyledons, 

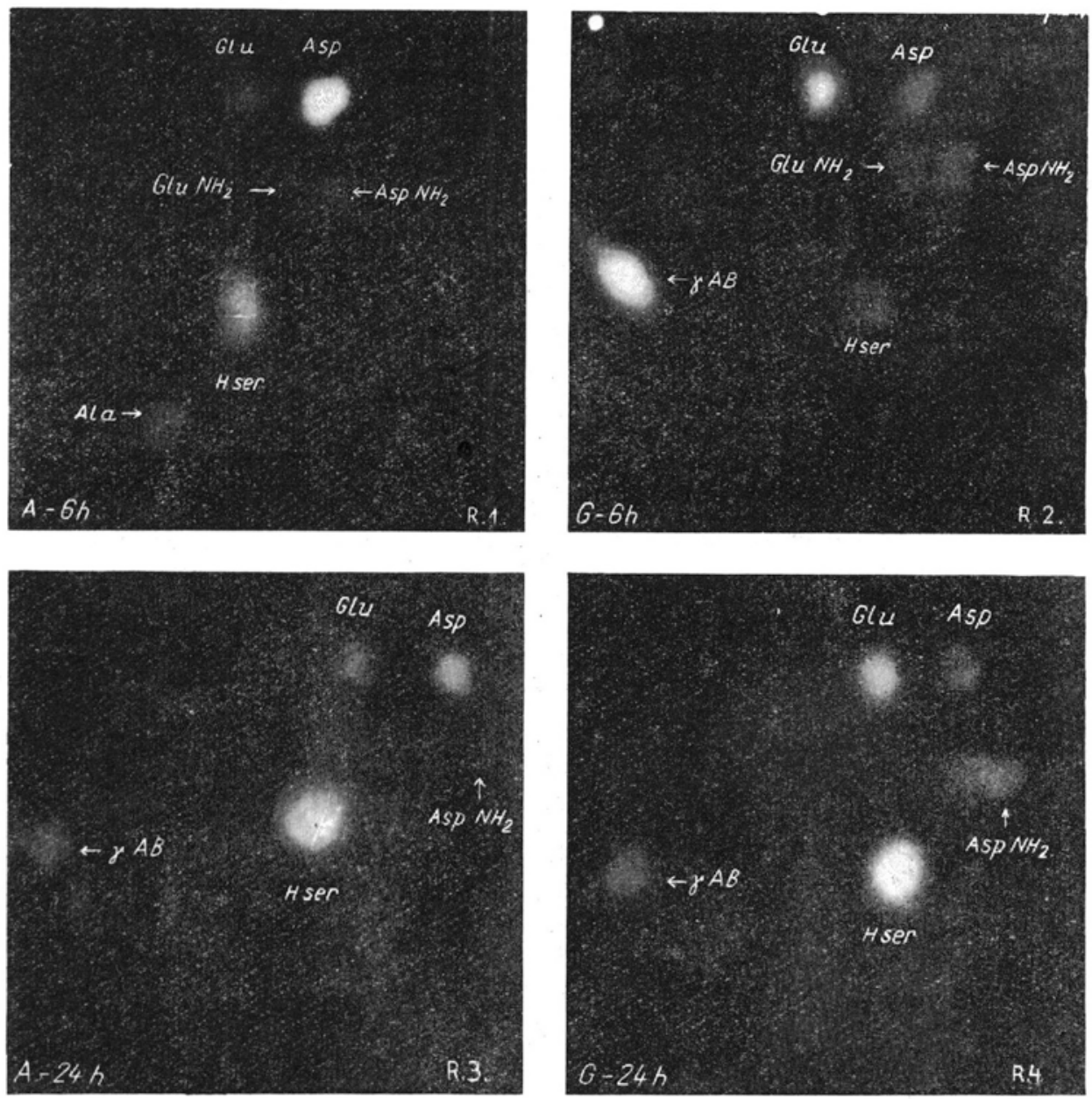

Fig. 4. Radioautograms of free amino acids of cotyledons of 5-day-old etiolated seedlings of Lathyrus sativus supplied with 14-C aspartic acid $(A)$ and 14-C glutamic acid $(G)-6$ and 24 hours after supplying the labelled compound.

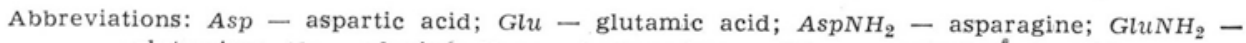
glutamine; Ala - alaniné; Hser - homoserine; $\gamma$-AB $-\gamma$-aminobutyric acid.

however, most of the radioactivity must be referred to other compounds. Paper electrophoresis of ninhydrin-negative products of hydrolysis of Fractions I, followed by radioactivity determinations on fragments of electropherograms, showed acidic compounds to be highly radioactive. Thus, compounds largely contributing to the radioactivity of Fractions I probably represent different organic acids.

Contribution of amino acids to the total radioactivity of Fraction I grew higher 24 hours after administration of a labelled compound. Pro- 


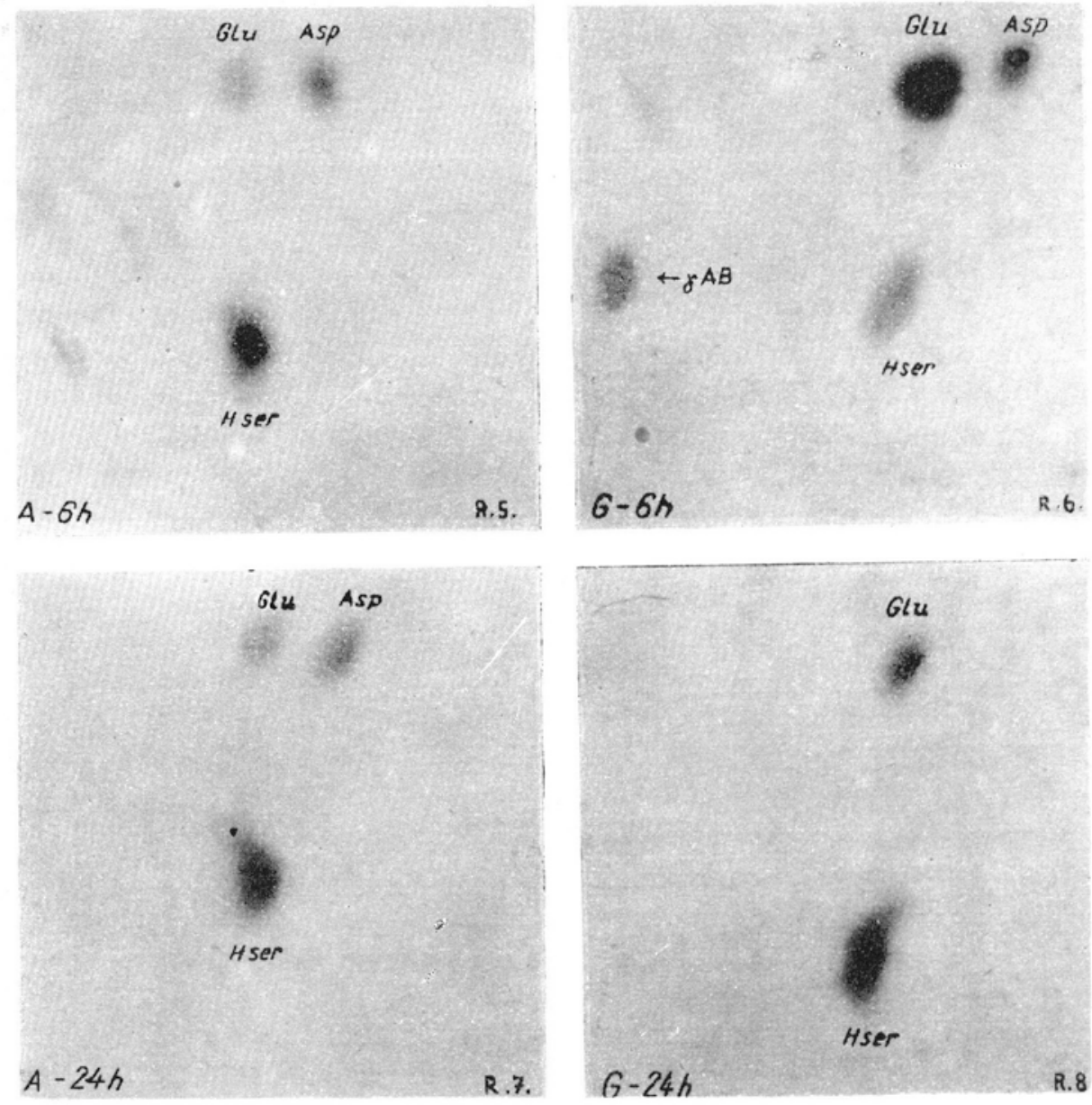

Fig. 5. Radioautograms of amino acids liberated on hydrolysis of Fraction I of cotyledons of 5-day-old etiolated seedlings of Lathyrus sativus supplied with 14-C aspartic acid $(A)$ and $14-\mathrm{C}$ glutamic acid $(G)-6$ and 24 hours after supplying the labelled compound.

Abbreviations as in fig. 4.

gressive acylation of radioactive amino acids might be responsible for this increase.

Figure 5 presents radioautograms of amino acids liberated on hydrolysis of Fractions I of cotyledons of seedlings supplied with 14-C aspartic acid and 14-C glutamic acid. Marked differences in radioactivity distribution among the amino acids, depending on the substrate supplied, may be observed after 6 hours from application of the radioactive compound. When 14-C aspartic acid was applied, homoserine represented the principal radioactive amino acid and less radioactivity was revealed in 
aspartic and glutamic acids. In the case of supplying 14-C glutamic acid very strong radioactivity was revealed in glutamic acid, and only weak radioactivity was found in homoserine, aspartic acid and $\gamma$-aminobutyric acid. Twenty four hours after supplying either aspartic or glutamic acid labelled with 14-C the main radioactive amino acid in hydrolysates of Fractions I proved to be homoserine. The data show, in accordance with those provided by radioautography of free amino acids, that aspartic acid is converted to homoserine more rapidly than glutamic acid.

As O-oxalylhomoserine is considered to be responsible for the appearance of homoserine in hydrolysates of Fractions I, the above presented results provide evidence on an oxalylation of the radioactive homoserine formed from the labelled precursors supplied. Moreover, on assuming that all amino acids liberated on hydrolysis of Fractions I derive from corresponding oxalyl amino acids, the data obtained indicate oxalylation of some other radioactive amino acids, namely aspartic acid, glutamic acid, and $\gamma$-aminobutyric acid. Very high radioactivity of glutamic acid yielded on hydrolysis of Fraction I of cotyledons, after 6 hours from administration of 14-C glutamic acid to the etiolated seedlings, may result from high rate of acylation of glutamic acid and/or from relatively slow metabolic utilization of its acyl derivative.

The relative radioactivity of homoserine yielded on hydrolysis of Fractions I proved to be higher in roots and shoots than in cotyledons of seedlings supplied with radioactive amino acids. A preferable transport of O-oxalylhomoserine from cotyledons to root-shoot axes may be hence inferred.

\section{Radioactivity distribution in Fractions II}

As revealed by radioautography of hydrolysis products of Fraction II, very weak relative radioactivity of these fractions was due to small amounts of dicarboxylic amino acids yięlded on hydrolysis. In no case radioactivity was observed in diaminopropionic acid.

III. RADIOACTIVITY DISTRIBUTION IN AMMONIA TREATED ETHANOLIC EXTRACTS OF EXCISED SHOOT APICES, LEAVES AND YOUNG PODS OF LATHYRUS SATIVUS SUPPLIED WITH 14-C ASPARTIC ACID, AFTER SIX HOURS FROM ADMINISTRATION OF THE LABELLED COMPOUND

The excised parts of green plants of Lathyrus sativus, after 6 hours from supplying 14-C aspartic acid, exhibited relatively high radioactivity in fractions containing free amino acids. Radioactivity of Fractions I proved to be lower, and only slight radioactivity has been revealed in Fractions II (Tab. 4). 
Table 4

Radioactivity distribution in ammonia-treated ethanolic extracts of shoot apices, leaves and young pods of Lathyrus sativus -6 hours after administration of $14-\mathrm{C}$ aspartic acid. Expressed in cpm/1 organ $\times 10^{-2}$

\begin{tabular}{l|c|c|c}
\hline \multirow{2}{*}{ Plant organs } & \multicolumn{3}{|c}{ Fractions* } \\
\cline { 2 - 4 } & I & II & III \\
\hline Shoot apices & $344(265)^{* * *}$ & 80 & 1005 \\
Leaves & $565(240)$ & 39 & 1150 \\
Young pods & $517(369)$ & 46 & 1270 \\
\hline
\end{tabular}

*, ** Explanations are given in Table 3
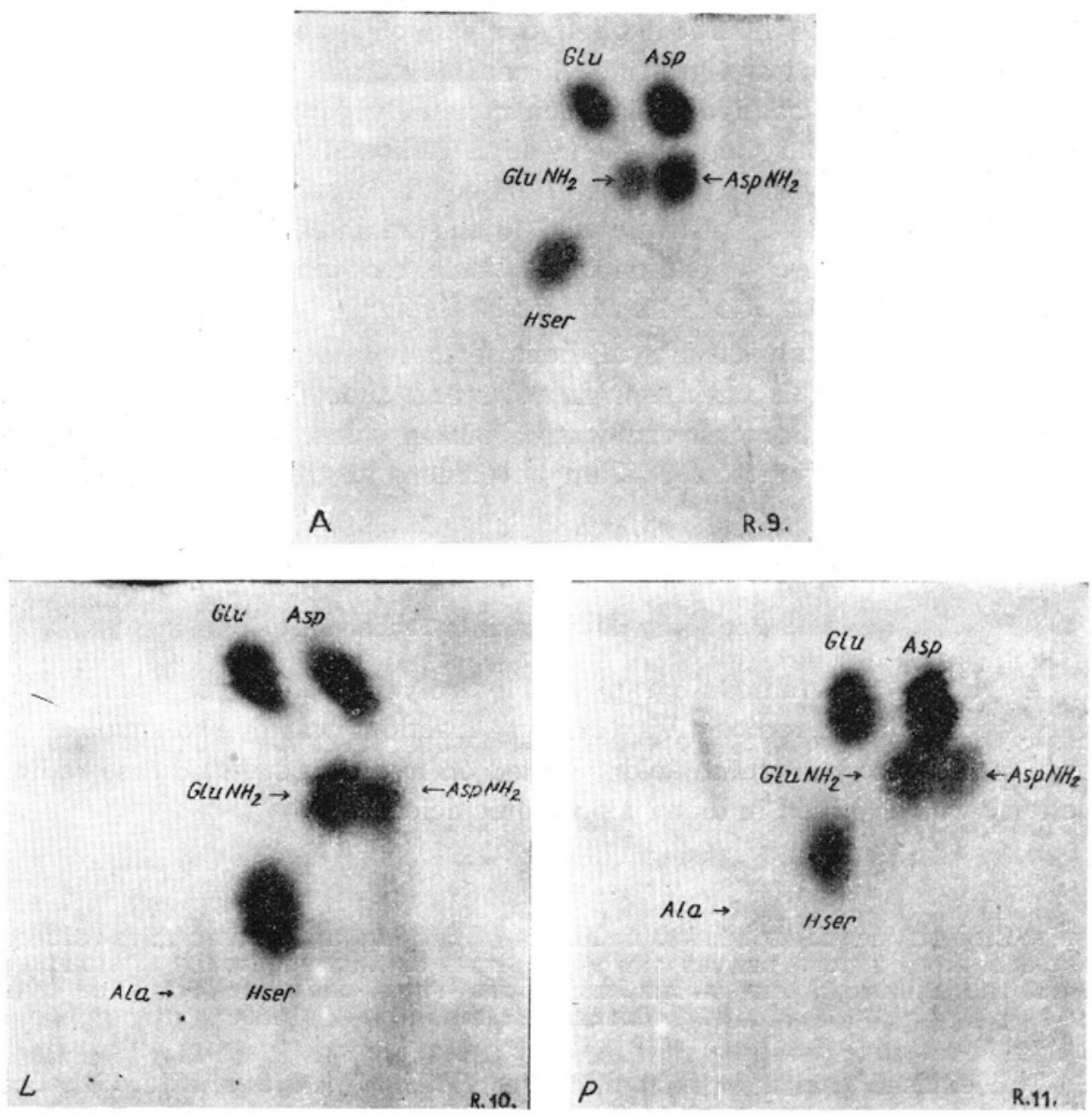

Fig. 6. Radioautograms of free amino acids of shoot apices $(A)$, leaves $(L)$, and of young pods $(P)$ of Lathyrus sativus supplied with 14-C aspartic acid -6 hours after isupplying the labelled compound. 


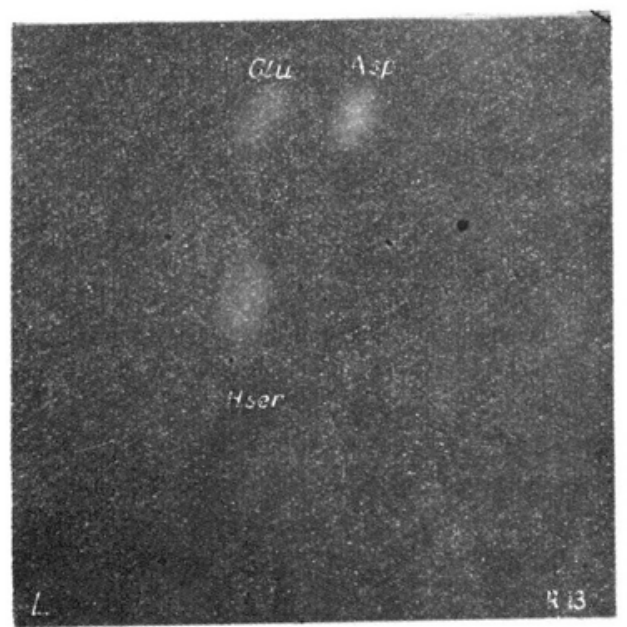

Fig. 7. A radioautogram of amino acids liberated on hydrolysis of Fraction I of leaves of Lathyrus sativus supplied with 14-C aspartic acid -6 hours after supplying the labelled compound.

Abbreviations as in fig. 4.

Radioactivity distribution among free amino acids in the excised parts of green plants supplied with 14-C aspartic acid was similar to that observed in cotyledons of etiolated seedlings from the corresponding experiment. It should be noticed, however, that in shoot apices and young pods the relative radioactivity found in homoserine was lower. In leaves and in young pods high relative radioactivity of glutamic acid and glutamine is to be emphasized (Fig. 6).

Radioautography of amino acids liberated on hydrolysis of Fractions I of the examined organs showed homoserine, aspartic acid and glutamic acid to be approximately equally labelled compounds (Fig. 7). As in hydrolysates of Fractions I both aspartic and glutamic acids were present in trace amounts only, it appears that the amino acids were actively acylated to corresponding derivatives which did not accumulate because of fast metabolic utilization.

Slight radioactivity of Fractions II was due to trace amounts of dicaboxylic amino acids liberated on hydrolysis of these fractions.

IV. RADIOACTIVITY DISTRIBUTION IN O-OXALYLHOMOSERINE IN EXCISED SHOOT APICES, LEAVES AND YOUNG PODS OF LATHYRUS SATIVUS SUPPLIED WITH 14-C OXALIC ACID, AFTER SIX HOURS FROM ADMINISTRATION OF THE LABELLED COMPOUND

The ammonia-treated ethanolic extracts of the excised parts of $\mathrm{La}$ thyrus sativus supplied with 14-C oxalic acid were chromatographed on ion-exchange columns and Fractions I collected. Fraction I of each extract was subsequently subjected to paper electrophoresis and the com- 
pound corresponding by mobility to N-oxalylhomoserine eluted with $50 \%$ ethanol. Further purification of $\mathrm{N}$-oxalylhomoserine was achieved by means of one-dimensional paper chromatography. N-oxalylhomoserine, eluted from the chromatogram, was hydrolysed and the hydrolysis products separated on paper electropherograms. In case of every organ examined distinct radioactivity was revealed in the area corresponding to oxalic acid while no radioactivity was found on the fragments of electropherograms which corresponded to homoserine lactone. The results suggest that oxalic acid was incorporated into O-oxalylhomoserine as an intact moiety.

Incorporation of oxalic acid, as an intact moiety, into O-oxalylhomoserine would involve activation of oxalic acid. Giovanelli and Tobin (1964) provided evidence that in the plant system the initial activation of oxalate proceeds directly via a synthetase reaction, and G i ovanelli (1966) has established the presence of oxalyl-CoA synthetase in Pisum. Later, M a lathi and coworkers (1967) have demonstrated this enzyme in crude extracts of Lathyrus sativus seedlings. Also, in the present investigations the activity of oxalyl-CoA synthetase in seedlings and shoot apices of Lathyrus sativus has been shown. M a l a th i, P a d$\mathrm{m}$ a n a b a n and S a r m a $(1968,1970)$ studied oxalytation of different amino acids by enzyme preparations from Lathyrus sativus and concluded that the $\beta-\mathrm{NH}_{2}$ group of DAP was the most favoured site for oxalylation; the affinity of a functional group for enzymatic oxalylation followed the order: $\beta-\mathrm{NH}_{2}$ group of DAP $>\gamma-\mathrm{NH}_{2}$ group of $\alpha, \gamma$-diaminobutyric acid $>\alpha-\mathrm{NH}_{2}$ group of homoserine or serine $>\gamma-\mathrm{OH}$ group of homoserine $>$ $\beta-\mathrm{OH}$ group of serine.

\section{GENERAL DISCUSSION}

Data obtained in the present studies indicate a significant resemblance of amino acid metabolism of Lathyrus sativus to that of Pisum sativum. The similarity concerns mainly an apparent implication of homoserine and its O-acyl derivative in nitrogen metabolism of these species.

Numerous investigations have been carried out on free amino acids in Pisum sativum. As pointed out by different researches, homoserine, undetected or found only in scarce amount in ungerminated seeds, arises rapidly during germination to attain after several days the status of a prominent free amino acid (Virtanen, Berg, K ari 1953; Berg, Kari, Alfthan, Virtanen 1954; Sas a oka 1958; Lawrence, Grant 1963; Larson, B e evers 1965; Grant, Voelkert 1970). Homoserine has been likewise observed, usually as an abundant free amino acid, in different organs at all phases of the development of pea plants (Miettinen, Kari, Moisio, A lfthan, Virtanen 1953; Miet- 
tinen 1955; Grobbelaar, Steward 1969; Przybylska, Rymowicz-D ą browska 1970). An acyl derivative of homoserine, namely O-acetylhomoserine, has been revealed in stems, leaves and developing fruits of Pisum sativum; the compound was a prominent free amino acid in young pericarps (Gro b b e la a r, S t e w a r d 1958, 1969). The data are strikingly parallel to those reported for Lathyrus sativus, the difference concerning mainly the acyl moiety of an O-acyl derivative of homoserine; the acetyl one is characteristic of Pisum sativum, while the oxalyl one - of Lathyrus sativus. It should be mentioned in this place that studies carried out in this laboratory showed not only in Lathyrus sativus but also in some other Lathyrus species a remarkable participation of homoserine and its O-oxalylderivative in free amino acid pool (Przybylska 1963, 1964; Przy by lska, Rymowicz 1965). Moreover, Simola (1968) reported homoserine to be one of the prominent free amino acid in various organs at every stage of development of Lathyrus sylvestris.

There have been performed extensive investigations on the biosynthesis of homoserine in Pisum sativum. R a b o n and Tolbert (1957), and $\mathrm{Naylor}, \mathrm{Rabs}$ on and Tolbert (1958) reported the formation of radioactive homoserine from 14-C aspartic acid in excised roots, leaves and young fruits of Alaska pea plants. S a s a o k a (1958) found incorporation of 14-C from 14-C labelled aspartic acid into homoserine in germinating pea seeds. Later studies of this investigator ( $\mathrm{S}$ a s a oka 1961) indicated the homoserine dehydrogenase activity in pea seedlings and led to the conclusion that the mechanism of homoserine biosynthesis in germinating pea seeds is similar to that in yeast.

Detailed studies on amino acid metabolism in young seedlings of $\mathrm{Pi}$ sum sativum were carried out by L a r s o n and B e e vers (1965). The studies covered, among others, isotopic experiments in which seedlings were supplied with different radioactive substrates, including 14-C aspartic acid and 14-C glutamic acid. Results concerning fate of the above amino acids in pea seedlings and the corresponding data, obtained in the present investigations for Lathyrus sativus, show similar trends. In etiolated seedlings of both species aspartic acid proved to be more efficiently converted to homoserine than glutamic acid. At early time after having supplied the seedlings of either Pisum sativum or Lathyrus sativus with 14-C glutamic acid, $\gamma$-aminobutyric acid proved to be the strongly labelled amino acid in cotyledons - later on, an increase of radioactivity in homoserine was observed. The results obtained both for Pisum sativum and for Lathyrus sativus indicate that homoserine produced in cotyledons is subsequently transferred to the root-shoot axes.

Indirect support for the thesis that aspartic acid is a precursor of homoserine in Pisum sativum came from the studies of $\mathrm{Gr}$ ob b e la a r and Steward (1969) on the influence of environment on the forma- 
tion of homoserine and $\mathrm{O}$-acetylhomoserine. There was found a conside rable effect of night temperature on the absolute and relative concentration of homoserine and O-acetylhomoserine in pea shoots; the lower was the night temperature the higher was the concentration of homoserine and its O-acetyl derivative. The night temperature had an opposite effect on asparagine. The contrasted effect of night temperature on concentration of asparagine, on the one hand, and on level of homoserine and $\mathrm{O}$-acetylhomoserine on the other, is consistent with the thesis ,,... that these amino acids are competitively derived from a common precursor, such as aspartic acid" (cited after: Grobbela ar, Stew a rd 1969). A dynamic state of metabolic equilibrium between homoserine and O-acetylhomoserine was inferred by Grobbelaar and Steward from the similar effect of the night temperature on the concentrations of the two closely related compounds.

Data provided by the present investigations indicate that the molar ratio of homoserine to its O-oxalyl derivative in Lathyrus sativus varies depending on the organ and developmental phase of the plant. Concerning etiolated seedlings, first prevailed homoserine and later on - O-oxalylhomoserine; the predominance of O-oxalylhomoserine over homoserine was especially evident in the root-shoot axes of five-day-old seedlings. As regards the analysed parts of green plants, the ratio of O-oxalylhomoserine to homoserine was higher in shoot apices and young fruits than in leaves. The data suggest a rapid transport of O-oxalyl derivative of homoserine to the youngest parts of Lathyrus sativus plants. It would be interesting to check whether in Pisum sativum the relationships between homoserine and its O-acetyl derivative show similar trends.

The role of homoserine in amino acid metabolism has been more fully studied in microorganisms and in animals than in higher plants. The significance of homoserine in threonine and methionine biosynthesis in microorganisms has been well established ( $\mathrm{M}$ e is t e $\mathrm{r}$ 1965). In the recent studies evidence has been obtained that O-succinylhomoserine is an intermediate in methionine biosynthesis in bacteria ( $\mathrm{R}$ ow bury 1962; Rowbury, Woods 1964; Flavin, Delavier-Klutchko, Slaughter 1964; Delavier-Klutchko, Flavin 1965; Kaplan, Flavin 1965; Flavin, Slaughter 1967), while O-acetylhomoserine is an intermediate in methionine biosynthesis in fungi ( $\mathrm{F}$ l a $\mathrm{v}$ i $\mathrm{n}$, Slaughter 1964; N a ga i, Flavin 1967; K err, Flavin 1968). $\mathrm{G}$ i ov a nelli and $\mathrm{Mudd}$ studied the reactions involved in methionine biosynthesis using enzyme extracts of spinach. The investigators reported O-acetylhomoserine and O-succinylhomoserine to be effective in enzymatic synthesis of cystathionine ( $\mathrm{G}$ i o vanelli, M udd 1966). They provided likewise evidence for specificity of O-acetylhomoserine in the for- 
mation of homocysteine ( $\mathrm{G}$ i o vane lli, M u d d 1967), and for biosynthesis of methionine from O-acetylhomoserine and methylmercaptan (G i o v a n e lli, M u d d 1968). Unpublished experiments of G i o v e n e l$\mathrm{li}$ and $\mathrm{M} \mathrm{u}$ d d (mentioned in: G i o v a n e $11 \mathrm{i}, \mathrm{M} \mathrm{u} d \mathrm{~d}$ 1967) indicated that O-oxalylhomoserine was active in the incorporation of cysteine into cystathionine in enzyme extracts of spinach. All these data indicate the physiological significance of O-acyl derivatives of homoserine. However, full appreciation of this significance requires further studies on distribution of these compounds and their involvement in enzymatic reactions in the plant kingdom.

\section{SUMMARY}

There were followed changes in free amino acid composition in Lathyrus sativus during 5 days of germination in the dark. There were also examined free amino acid pools in various parts of green plants, i.e. in shoot apices and leaves at time of bloom and in young pods.

Isotopic experiments covered application of 14-C aspartic acid and 14-C glutamic acid to 5-day-old etiolated seedlings, and administration of 14-C aspartic acid and 14-C oxalic acid to detached parts of green plants. Ethanolic extracts of the supplied materials were fractionated by means of ion-exchange column chromatography and radioactivity distribution among individual fractions was determined. There was likewise determined radioactivity distribution within individual fractions.

The most characteristic feature of the amino acid metabolism in germinating seeds of Lathyrus sativus proved to be a rapid increase of homoserine and its O-oxalyl derivative - the compounds, undetected in ungerminated seeds, achieved high relative levels in 5-day-old etiolated seedlings. Especially high levels of O-oxalylhomoserine were observed in root-shoot axes of the seedlings. In all the examined parts of green plants homoserine and its O-oxalyl derivative largely contributed to the free amino acid pool.

Isotopic experiments with etiolated seedlings indicated that aspartic acid was more rapidly converted to homoserine than glutamic acid. At early time after 14-C glutamic acid had been administered to the etiolated seedlings a remarkable radioactivity was found in $\gamma$-aminobutyric acid; later on an increase of radioactivity in homoserine was observed. An evidence has been likewise provided on an oxalylation of homoserine. The obtained data indicated a transport of homoserine and O-oxalylhomoserine from cotyledons to the growing parts.

Experiments with excised shoot apices, leaves and young pods supplied with 14-C aspartic acid showed, like those with etiolated seedlings, formation of homoserine from this substrate, and indicated oxalylation of homoserine. In leaves and young pods aspartic acid was efficiently converted to glutamic acid and glutamine.

Examination of radioactivity distribution in O-oxalylhomoserine in excised shoot apices, leaves and young pods of Lathyrus sativus supplied with 14-C oxalic acid led to the conclusion that oxalic acid was incorporated into O-oxalylhomoserine as an intact moiety.

In ethanolic extracts of both etiolated seedlings and detached parts of green plants supplied with labelled amino acids a considerable radioactivity was found in ninhydrin-negative acidic compounds - apparently different organic acids. Ra- 
dioactivity has been likewise revealed in aspartic and glutamic acids liberated on hydrolysis of ninhydrin-negative acidic compounds - probably the corresponding. oxalyl amino acids.

The obtained results have been mainly discussed with reference to the similarity of amino acid metabolism of Lathyrus sativus and that of Pisum sativum.

\section{Acknowledgements}

The author is greatly indebted to Professor dr J. Pawe łkiewicz (Department of Biochemistry, College of Agriculture, Poznań) for creative discussions and valuable advices during performing these studies as well as for critical reading the manuscript. An excellent technical assistance of Mrs. Z. Przyby $1 \mathrm{ska}$ is gratefully acknowledged.

This work was supported in part by a rescarch grant from the U.S. Department of Agriculture.

\section{REFERENCES}

B el1 E. A., 1962a, Associations of ninhydrin-reacting compounds in the seeds of 49 species of Lathyrus, Biochem. J. 83: 225-229.

B e 11 E. A., 1962b, The isolation of L-homoarginine from seeds of Lathyrus cicera, Biochem. J. 85: 91-93.

Berg A. M., Kari S., Alfthan M., Virtanen A. I., 1954, Homoserine and $\alpha$-aminoadipic acid in green plants, Acta Chem. Scand. 8: 358.

Bray G. A., 1960, A simple efficient liquid scintillator for counting aqueous solutions in a liquid scintillation counter, Anal. Biochem. 1: 279-235.

Chwałek B., Przybylska J., 1970, L-Homoarginine in Lotus helleri, Bull. Acad. Polon. Sci., Ser. sci. biol. 18: 603-605.

Delavier-Klutchko C., Flavin M., 1965, Enzymatic synthesis and cleavage of cystathionine in fungi and bacteria, J. Biol. Chem. 240: 2537-2549.

Flavin M., Delavier-Klutchko C., Slaughter C., 1964, Succinic ester and amide of homoserine: some spontaneous and enzymatic reactions, Science 143: 50-52.

Flavin M., Slaughter C., 1964, Cystathionine cleavage enzymes of Neurospora, J. Biol. Chem. 239: 2212-2219.

Flavin M., Slaughter C., 1965, Synthesis of the succinic ester of homoserine, a new intermediate in the bacterial biosynthesis or methionine, Biochemistry 4: $137 \mathrm{C}-1375$.

Flavin M., Slaughter C., 1967, Enzymatic synthesis of homocysteine or methionine directly from O-succinylhomoserine, Biochim. Biophys. Acta 132: $400-405$.

Giovane11i J., 1966, Oxalyl-coenzyme A synthetase from pea seeds, Biochim. Biophys. Acta 118: 124-143.

Giovanelli J., Mudd S. H., 1966, Enzymatic synthesis of cystathionine by extracts of spinach, requiring O-acetylhomoserine or O-succinylhomoserine, Biochem. Biophys. Res. Commun. 25: 366-371.

Giovanelli J., Mudd S. H., 1967, Synthesis of homocysteine and cysteine by enzyme extracts of spinach, Biochem. Biophys. Reis. Commun. 27: 150-156.

Giovanelli J., Mudd S. H., 1968, Sulfuration of O-aceitylhomoserine and O-acetylserine by two enzyme fractions from spinach, Biochem. Biophys. Res. Commun. 31: 275-280. 
Giovanelli J., Tobin N. F,, 1964, Enzymic decarboxylation of oxalate by extracts of plant tissue, Plant Physiol. 39: 139-145.

Grobbela ar N., Steward F. C., 1958, O-acetylhomoserine in Pisum, Nature 182: $1358-1359$,

Grobbelaar N., Steward F. C., 1969, The isolation of amino acids from Pisum sativum. Identification of $\mathrm{L}(-)$-homoserine and $\mathrm{L}(+)-\mathrm{O}$-acetylhomoserine and certain effects of environment upon their formation, Phytochemistry 8: $553-559$.

Grant D. R., 1963, Reagent stability in Rosen's ninhydrin method of analysis of amino acids, Anal. Biochem. 6: 109-110.

Grant D. R., Voelkert E., 1970, The effect of temperature and light on the accumulation of homoserine in pea seedlings, Phytochemistry 9: 985-990.

Hartley R. D., Lawson G. J., 1960, Improved methods for the paper chromatography of organic acids, J. Chromatogr. 4: 410-413.

K a plan M. M., Flavin IM., 1965, Enzymatic synthesis of L-cylstathionine from the succinic ester of L-homoserine, Biochim. Biophys. Acta 104: 390-396.

Kerr D. S., Flavin M., 1968, Synthesis of cystathionine from O-acetylhomoserine in Neurospora: a step in methionine biosynthesis, Biochem. Biophys. Res. Commun. 31: 124-130.

Larson L. A., Beevers H., 1965, Amino acid metabolism in young pea seedlings, Plant Physiol. 40: 424-432.

L a wrence J. M., Grant D. R., 1963, Nitrogen mobilization in pea seedlings. II. Free amino acids, Plant Physiol. 38: 561-566.

Malathi K., Padmanaban G., Ra o 'S. L. N., Sarma P. S., 1967, Studies on the biosynthesis of $\beta$-N-oxalyl-L- $\alpha, \beta$-diaminopropionic acid, the Lathyrus sativus neurotoxin, Biochim. Biophys. Acta 141: $71-78$.

Malathi K., Padmanaban G., Sarma P. S., 1968, Oxalylation of some amino acids by an enzyme preparation from Lathyrus sativus, Indian J. Biochem: $5:$ 184-185.

Malathi K., Padmanaban G., Sarma P. S., 1970, Biosynthesis of $\beta$-N-oxalyl-L- $\alpha, \beta$-diaminopropionic acid, the Lathyrus sativus neurotoxin, Phytochemistry 9: 1603-1,610.

M e ister A., 1965, Biochemistry of the amino acids, New York, Academic Press. Mi ettine n J. K., 1955, Free amino acids in the pea plant (Pisum sativum), Ann. Acad. Scient. Fennicae A II, 60: 520-535.

Miettinen J. K., Kari S., Moisio T., Alfithan M., Virtanen A. I., 1953, Homoserine als freie Aminosäure in Erbsenpflanzen (Pisum sativum), Suomen Kemistelehti B 26: 26-30.

M o ore S., Stein W. H., 1954, A modified ninhydrin reagent for the photometric determination of amino acids and related compounds, J. Biol. Chem. 211: 907-913.

Murti V. V. S., Seshadri T. R., Venkitasubramanian T. A., 1964, Neurotoxic compounds of the seeds of Lathyrus sativus, Phytochemistry 3: 73-78.

Nagai S. Flavin M., 1967, Acetylhomoserine. An intermediate in the fungal biosynthesis of methionine, J. Biol. Chem. 242: 3884-3895.

Naylor A. W., Rabson R., Tolbert N. E., 1958, Aspartic-C ${ }^{14}$ acid metabolism in leaves, roots and stemis, Physiol. Plantarum 11: 537-547.

Przyby 1ska J., 1960, Forms of organic nitrogen and their changeability in certain species and varieties of lupin, Genet. Polon. 1: 145-173.

Przybylska J., 1963, Homoserine in various species of the genus Lathyrus, Bull. Acad. Polon. Sci., Ser. isci. biol. 11: 317-319.

Prz y b y lska J., 1964, The role of tingitanine in nitrogen metabolism of Lathyrus tingitanus, Acta Soc. Bot. Polon. 33: 211-241. 
Przybylska J., Pawełkiewicz J., 1965, O-oxalylhomoserine, a new homoserine derivative in young pods of Lathyrus sativus, Bull. Acad. Polon. Sci., Ser. sci. biol. 13: 327-329.

Przyby lska J., Rymowicz T., 1965, Free amino acids in different organs of 16 Lathyrus species, Genet. Polon. 6: 91-124.

Przybylska J., Rymowicz-Dąbrowska T., 1970, Wolne aminokwasy w roślinach pasitewnych. I. Wolne aminokwasy w różnych organach niektórych gatunków jednorocznych roślin motylkowych, Roczn. Nauk Roln. 96-A-3: $189-201$.

Rabson R., Tolbert N. E., 1957, Biosynthesis of homoserine from aspartic acid in Alaska peas, Plant Physiol. Supl. 32: xxxv. Proceedings of the Plant Physiology meetings held at Stanford University, California.

Rosen H., 1957, A modified ninhydrin colorimetric analysis for amino acids, Arch. Biochem. Biophys. 67: 10-15.

Rowbury R. J., 1962, A succinyl derivative of homoserine as a precursor of methionine in Escherichia coli, J. gen. Microbiol. 28: v-vi.

Rowbury R. J., Woods D. D., 1964, O-succinylhomoserine as an intermediate in the synthesis of cystathionine by Escherichia coli, J. gen. Microbiol. 36: $341-358$.

Sasaoka K., 1958, Studies on the formation of homoserine during the germination of the pea, Mem. Res. Inst. Food Sci. (Kyoto Univ.) 14: 42-48.

S a s a o k K., 1961, Studies on homoserine dehydrogenase in pea seedlings, Plant and Cell Physiol. 2: 231-242.

Simola L. K., 1968, Comparative studies on the amino acid pools of three Lathyrus species, Acta bot. fenn. 81: 1-62.

S mith J., 1960, Chromotographic and electrophoretic techniques, London, W. Heinemann, Medical Books.

Virtanen A. I., Berg A. M., Kari S., 1953, Formation of homoserine in germinating pea seeds, Acta Chem. Scand. 7: 1423-1424.

Voelkert E., Grant D. R., 1970, Determination of homoserine as the lactone, Anal. Biochem. 34: 131-137.

W a gner J., 1958, Eine Kombinationsmöglichkeit von Papierelectrophorese und Papierchromatographie zur Trennung von Aminosäuren, Naiturwiss. 45: 1110-111.

Wolfe M., 1957, Determination of amino acids by paper chromatography. A solvent to replace phenol, Biochim. Biophys. Acta 23: 186-191.

\section{Metabolizm aminokwasów u Lathyrus sativus Biosynteza homoseryny i O-oksalylohomoseryny}

\section{Streszczenie}

Określono zmiany w składzie wolnych aminokwasów Lathyrus sativus w ciągu 5-dniowego okresu kiełkowania nasion w ciemności. Analizowano również skład wolnych aminokwaisów w różnych częściach zielonych roślin, a mianowicie w wierzchołkach pędów i w liściach w fazie kwitnienia oraz w młodych strąkach.

Do 5-dniowych etiolowanych siewek wprowadzono 14-C kwas asparaginowy i 14-C kwas glutamünowy, a do odciętych wierzchołków pędów, liści i młodych strąków - 14-C kwas asparaginowy i 14-C kwas szczawiowy. Etanolowe ekstrakty powyższego materiału frakcjonowano przy pomocy jonowymiennej chromatografii kolumnowej, po czym określano rozdział radioaktywności między wydzielone frakcje oraz w obrębie poszczególnych frakcji. 
Szczególnie charakterysityczną cechą metabolizmu aminokwasów 'w kiełkujących nasionach Lathyrus sativus okazał się szybki wzrost zawartości homoseryny oraz jej O-oksalylopochodnej — związki te, nie wykryte w nieskiełkowanych nasionach, osiągnęły wysoki względny poziom w 5-dniowych etiolowanych siewkach. $\mathrm{Na}$ podkreślenie zasługuje bardzo wysıoki poziom O-oksalylohomoseryny w osiach siewek.

Skład wolnych aminokwasów wierzcholków pędów i liści w fazie kwitnienia oraz młodych strąków był zbliżony i charakteryzował się wysokim udziałem homoseryny i O-oksalylohomoseryny.

Doswiadczenia $\mathrm{z}$ zastosowaniem radioaktywnych związków wykazały, że w etiolowanych siewkach Lathyrus sativus kwas asparaginowy szybciej przekształcał się do homoseryny niż kwas glutaminowy. Po wprowadzeniu 14-C kwasu glutaminowego do etiolowanych siewek obserworwano znaczną radioaktywność kwasu $\gamma$-aminomasłowego i dopiero w późniejszym okresie stwierdzono wzrost radioaktywności homoseryny. W wyniku przeprowadzonych doświadczeń sitwierdzono oksalylację homoseryny oraz transport homoseryny i jej O-oksalylopochodnej z liścieni do części rosnących.

W wierzchołkach pędów, liściach i młodych strąkach Lathyrus sativus metabolizujących 14-C kwas asparaginorwy zaobserwowano, podobnie jak w etiolowanych siewkach, wyraźną radioaktywność homoseryny oraz stwierdzono jej oksalylację. W liściach oraz $\mathrm{w}$ młodych strąkach kwas asparaginowy był wydlajnie przekształcany do kwasu glutaminowego i glutaminy.

Badania nad rozdziałem radioaktywności w O-oksalylohomoserynie wyodrębnionej z organów, do których wprowadzono 14-C kwas szczawiowy, doprowadziły do wniosku, że kwas szczawiowy wbudowuje się w O-oksalylohomoserynę jako cała cząsteczka (,,intact moiety").

W etanolowych ekstraktach zarówno etiolowanych siewek, jak i zielonych części roślin, do których wprowadzono znaczone aminokwasy, znaczną radioaktywność stwierdzono w ninhydryno-ujemnych kwaśnych związkach - przypuszczalnie kwasach organicznych. Radiaktywność stwierdzono również w kwasie asparaginowym i glutaminowym uwolnionych w wyniku hydrolizy ninhydryno-ujemnych kwaśnych związków - prawdopodobnie odpowiednich oksalyloaminokwasów.

W omówieniu wyników zwrócono szczególną uwagę na wspólne cechy metabolizmu aminokwasów u Lathyrus sativus i u Pisum sativum. 